\title{
Effects of passive immunization against oestradiol-17 $\beta$ on some endocrine values of the male lamb
}

\author{
N. Jenkins*, P. G. Knight, C. M. Howles, B. A. Morris $\dagger$, and \\ G. M. H. Waites \\ Department of Physiology \& Biochemistry, University of Reading, Berks RG6 IAH; \\ * Biological Laboratory, University of Kent at Canterbury, Kent CT2 7NJ; and \\ $\dagger$ Division of Clinical Biochemistry, Biochemistry Department, Surrey University, Guildford, \\ Surrey GU2 $5 X H, U . K$.
}

\begin{abstract}
Summary. Passive immunization of male lambs against oestradiol-17 $\beta$ from 2 to 16 weeks of age significantly elevated androgen concentrations in plasma and depressed the median eminence content of dopamine. Removal of endogenous oestrogens had no significant effects on plasma FSH, LH or prolactin concentrations or on testicular growth and hypothalamic content of GnRH. These results suggest that endogenous oestrogens may indirectly suppress testicular androgen secretion by exerting a stimulatory influence on hypothalamic dopaminergic neurones, which in turn may inhibit GnRH secretion by the median eminence.
\end{abstract}

\section{Introduction}

Manipulation of circulating oestradiol concentrations by steroid implantation (Jenkins \& Waites, 1983) or by immunization (Land, Baird \& Carr, 1981) has provided evidence for a physiological role for oestrogens in the developing male lamb. Oestradiol implants induced a suppression of the secretion of LH and FSH in intact male lambs (Jenkins \& Waites, 1983) and in castrated rams (Schanbacher \& Ford, 1977; Alexander \& Miller, 1982), although normal endogenous concentrations of oestradiol-17 $\beta$ are $<15 \mathrm{pg} / \mathrm{ml}$ in adult rams (Sandford, Simaraks, Palmer \& Howland, 1982). Active immunization against oestradiol resulted in elevated circulating concentrations of testosterone and LH in male rats (Nishihara \& Takahashi, 1983) and in adult rams (Schanbacher, 1984) whereas no significant changes in plasma LH or FSH values were observed in male lambs passively immunized against oestradiol or oestrone (Land et al., 1981). The present study was therefore undertaken to determine the effects of passive immunization against oestradiol during the early prepubertal period, when gonadotrophin concentrations are most susceptible to the influences of testicular feedback (Lee, Bremner, Cumming, de Kretser \& Findlay, 1981; Waites, Speight \& Jenkins, 1985). In addition to the measurements of gonadotrophins and androgens in plasma, the contents of noradrenaline, dopamine dihydroxyphenylacetic acid (DOPAC, a major metabolite of dopamine) and GnRH in the brain were determined to differentiate between hypothalamic and pituitary targets for steroid feedback.

\section{Materials and Methods}

Animals. Twelve cross-bred male lambs (50\% Suffolk; $25 \%$ Blue-Faced Leicester; $25 \%$ Swaledale) born in March 1982 were reared in light-proof rooms, under a constant photoperiod (12 h light: $12 \mathrm{~h}$ dark). Lambs were separated from their ewes during the first week of life and weaned from milk substitute (Lamlac, Royston, U.K.) on to pelleted concentrates at 5 weeks of age. 
Testicular diameter (measured through the skin using vernier callipers) and body weights were measured at weekly intervals. Six 16-week-old lambs from the same flock were castrated at least 8 weeks before slaughter and were used solely to establish the hypothalamic contents of GnRH and amines at slaughter (see below).

Antiserum treatments. Three lambs were used as untreated controls, and 3 were given a control antiserum raised in sheep against a methetrexate-ovalbumin conjugate (MTXAB; Code HP/S/265) which has no affinity for steroids but contains antibodies to the carrier protein ovalbumin. Six lambs received an antiserum raised in sheep against an oestradiol-17 $\beta$-3-carboxymethyl-ovalbumin conjugate (EAB; code HP/S/721-15108; Land, Morris, Baxter, Fordyce \& Forster, 1982). A dilution of 1:231 (the mean EAB titre found after passive immunization) of this antiserum crossreacted $24 \%$ with oestrone, $1.6 \%$ with testosterone, $0.6 \%$ with $5 \alpha$-dihydrotestosterone (DHT) and $0.6 \%$ with androstenedione. Both antisera were dialysed for $48 \mathrm{~h}$ against $0.05 \mathrm{M}$-phosphatebuffered saline ( $\mathrm{pH} 7 \cdot 4$ ) before use to remove sodium azide preservative, and $1 \mathrm{ml}$ of the appropriate antiserum was injected into a jugular vein of each lamb at 14-day intervals from 2 to 14 weeks of age. One lamb immunized against oestradiol died from suspected bloat.

Plasma samples obtained at weekly intervals (see below) were tested at dilutions of 1:100 to $1: 1000$ for their ability to bind $\left[{ }^{3} \mathrm{H}\right]$ oestradiol- $17 \beta$ (Amersham International PLC, TRK322) using $0.2 \%$ charcoal coated with $0.02 \%$ Dextran $\mathrm{T} 70$ in phosphate-buffered saline to adsorb unbound steroid.

Blood sampling and assays for plasma hormone concentrations. Blood $(8-10 \mathrm{ml})$ was taken by jugular venepuncture between 10:00 and $11: 00 \mathrm{~h}$ at weekly intervals between 8 and 14 weeks of age. Intensive sampling ( $2 \mathrm{ml}$ taken every $30 \mathrm{~min}$ between 08:00 and 20:00 h) was performed every 4 weeks by means of a butterfly cannula implanted into a jugular vein $18 \mathrm{~h}$ previously. A single intravenous dose $(1 \mu \mathrm{g})$ of synthetic gonadotrophin releasing hormone (GnRH; Sigma Chemicals) was given at 17:00 h during intensive blood sampling to assess the pituitary response to exogenous releasing hormone. Blood samples were placed in heparinized tubes, centrifuged $(800 \mathrm{~g}, 10 \mathrm{~min})$, and the resultant plasma was stored at $-20^{\circ} \mathrm{C}$.

Plasma concentrations of LH, FSH and prolactin were determined by radioimmunoassay (Walton, McNeilly, McNeilly \& Cunningham, 1977) with mean coefficients of intra-assay variation of $9.5 \%, 11.5 \%$ and $12.2 \%$, and sensitivity limits of $0.98,54.0$ and $8.2 \mathrm{ng} / \mathrm{ml}$ respectively. All samples were analysed in a single assay for each hormone.

Androgen concentrations were determined by the non-extraction radioimmunoassay described by Howles, Webster \& Haynes (1980) using an antiserum which has $100 \%$ cross-section with testosterone, $44 \%$ with DHT, $2.4 \%$ with 5 -androsten-3 $\beta, 17 \beta$-diol and $<0.5 \%$ with androstenedione, androsterone, oestrone and oestradiol-17 (GW129/9; Webley, 1982). The intra-assay and interassay coefficients of variation were $9 \cdot 5 \%$ and $11.2 \%$ respectively, the limit of detection being $30 \mathrm{pmol} / \mathrm{l}$.

Preparation of hypothalamic extracts and assays for catecholamines and $G n R H$. All lambs were killed at 16 weeks of age and the testicular weights recorded. Immediately after death, brains were removed and a block of tissue containing the whole hypothalamus was isolated and frozen on solid $\mathrm{CO}_{2}$ within $10 \mathrm{~min}$. With the aid of a stereotaxic atlas of the sheep brain (Welento, Szteyn \& Milart, 1969) four subdivisions of the hypothalamus were dissected (dorso-medial area, ventromedial area, median eminence, and anterior hypothalamus-preoptic area; Fig. 1) and extracted using $0.05 \mathrm{M}-\mathrm{HCl}$ for subsequent determination of (i) catecholamines by high performance liquid chromatography with the inclusion of internal and external standards and (ii) GnRH by radioimmunoassay (Knight, Wilson, Gladwell \& Cunningham, 1984).

Statistics. Mean plasma hormone concentrations and tissue concentrations of amines and GnRH in the brain extracts were compared using Student's independent $t$ test. Antibody titres 


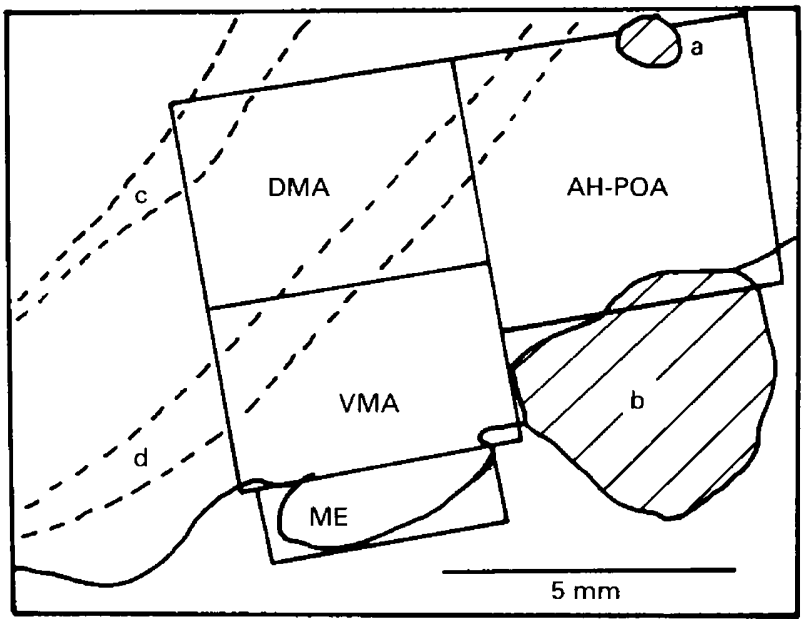

Fig. 1. Parasagittal section of sheep hypothalamus showing the four regions (dorsomedial area, DMA; ventromedial area, VMA; anterior hypothalamic-preoptic area, AH-POA; median eminence, ME) isolated for determination of GnRH and amine contents. a, Anterior commissure; $\mathrm{b}$, optic chiasma; c, tractus mamillothalamicus (projection); d, fornix (projection). Tracts $\mathrm{c}$ and $\mathrm{d}$ exist in planes $2.5 \mathrm{~mm}$ either side of the mid-line and mark the lateral limits of the DMA, VMA and AH-POA.

(serum dilution which binds $50 \%$ of $\left[{ }^{3} \mathrm{H}\right]$ oestradiol-17ß) were determined by the method of Nieschlag \& Wickings (1978).

\section{Results}

Average body weight $(3.78 \pm 0.12 \mathrm{~kg}$ at birth, $40.0 \pm 1.74 \mathrm{~kg}$ at 16 weeks $)$ and mean testicular diameter were similar in all groups throughout the study. Results obtained from untreated and MTXAB-treated control animals were not significantly different in any value measured, and they were combined to form a control group of 6 animals. Mean testicular weight at 16 weeks was similar in the control $(1.87 \pm 0.29 \mathrm{~g} / \mathrm{kg}$ body weight $)$ and EAB-treated $(2.07 \pm 0.27 \mathrm{~g} / \mathrm{kg}$ body weight $)$ animals. The mean plasma titre required to bind $6 \mathrm{pmol}\left[{ }^{3} \mathrm{H}\right]$ oestradiol-17 $\beta$ in EAB-treated lambs was 1:231 \pm 41 , and no significant oestradiol binding was observed in plasma from control animals.

Plasma from lambs bled at weekly intervals from 8 to 16 weeks of age showed a mean LH concentration of $3.4 \pm 1 \cdot 1 \mathrm{ng} / \mathrm{ml}$ in the EAB group which was not significantly different from that in controls $(2 \cdot 8 \pm 1 \cdot 1 \mathrm{ng} / \mathrm{ml})$; peak levels of $\mathrm{LH}$ were apparent at 10 weeks of age in both groups. Intensive blood sampling (every $30 \mathrm{~min}$ for $12 \mathrm{~h}$ ) did not reveal significant differences in LH pulse frequency or amplitude between groups. FSH and prolactin concentrations varied widely between animals (mean \pm s.e.m. concentrations: $73 \cdot 4 \pm 14 \cdot 1 \mathrm{ng} \mathrm{FSH} / \mathrm{ml} ; 19 \cdot 7 \pm 5.4 \mathrm{ng}$ prolactin $/ \mathrm{ml}$ ) but did not vary significantly with age or treatment. Mean plasma androgen concentrations were significantly higher in EAB-treated animals than in controls $(P<0.05)$ during intensive sampling at 12 and 16 weeks (Fig. 2a), whereas the mean values in samples taken $0 \cdot 5-3 \mathrm{~h}$ after GnRH stimulation were similar in both groups and increased linearly with age (Fig. 2b).

After slaughter at 16 weeks of age, the dopamine content of the median eminence was significantly greater in controls $(+111 \% ; P<0.05)$ than in EAB-treated lambs (Table 1). Moreover, the 

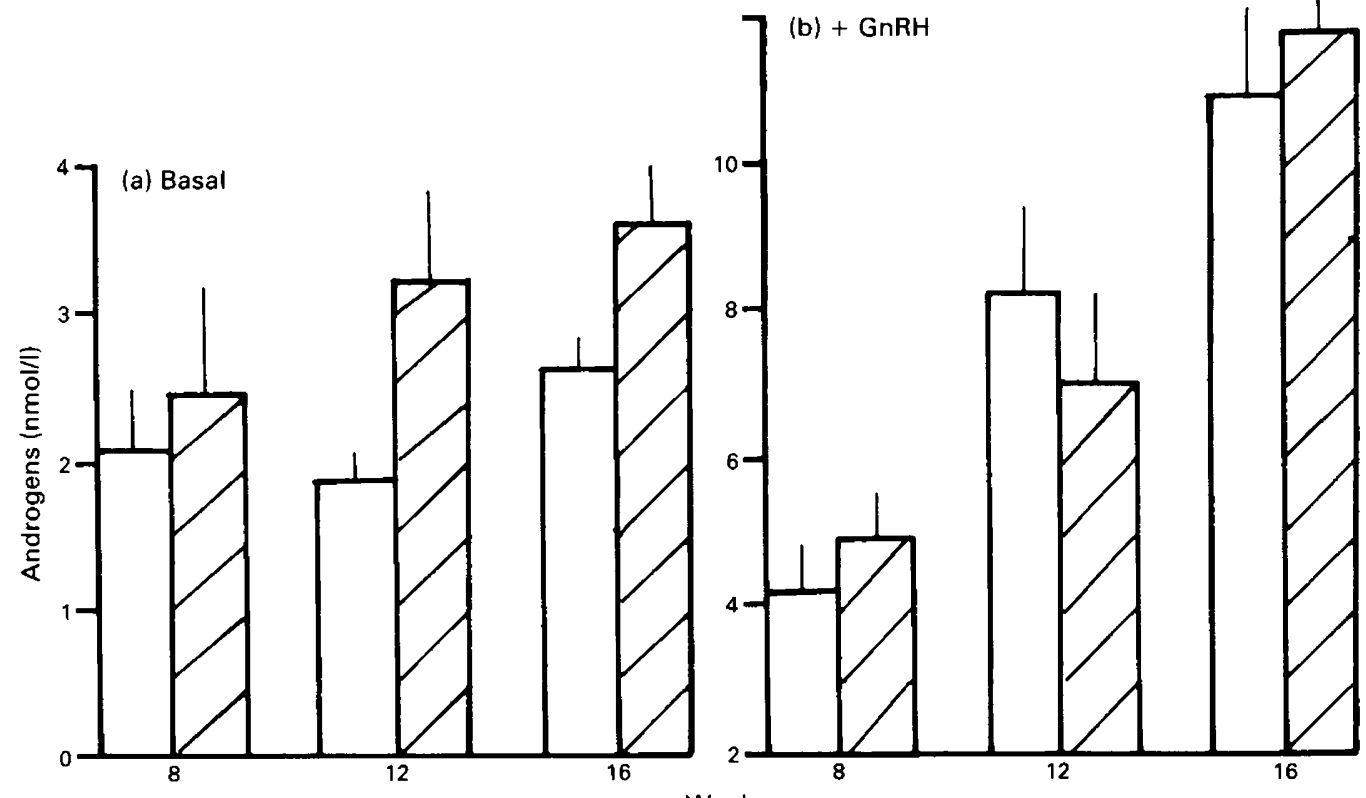

Fig. 2. Plasma androgen concentrations in jugular venous plasma of control lambs $(\square, N=6)$ and lambs immunized against oestradiol-17 $(\mathbb{Z}, \mathbf{N}=5)$ at various ages. (a) Mean \pm s.e.m. concentrations in plasma between $08: 00$ and 16:30 h. (b) Mean \pm s.e.m. concentrations in plasma $0 \cdot 5-3 \mathrm{~h}$ after intravenous administration of $1 \mu \mathrm{g} \mathrm{GnRH}$ (i.e. 17:30-20:00 h).

Table 1. Concentrations (mean \pm s.e.m.) of dopamine, dihydroxphenylacetic acid (DOPAC), noradrenaline and $\mathrm{GnRH}$ in four hypothalamic regions (median eminence, ME; ventromedial area, VMA; dorsomedial area, DMA and anterior hypothalamic-. preoptic area, AH-POA) in 6 intact control lambs, 6 castrated lambs (cast.) and 5 intact lambs passively immunized against oestradiol-17ß (EAB)

\begin{tabular}{|c|c|c|c|c|c|}
\hline Region & Lambs & $\begin{array}{c}\text { Dopamine } \\
\text { (ng/mg) }\end{array}$ & $\begin{array}{c}\text { DOPAC } \\
(\mathrm{ng} / \mathrm{mg})\end{array}$ & $\begin{array}{l}\text { Noradrenaline } \\
\quad(\mathrm{ng} / \mathrm{mg})\end{array}$ & $\begin{array}{c}\text { GnRH } \\
(\mathrm{pg} / \mathrm{mg})\end{array}$ \\
\hline $\mathrm{ME}$ & $\begin{array}{l}\text { Control } \\
\text { Cast. } \\
\text { EAB }\end{array}$ & $\begin{array}{l}0.78 \pm 0.09 \\
0.58 . \pm 0.06 \\
0.37 \pm 0.11^{*}\end{array}$ & $\begin{array}{l}2.44 \pm 0.21 \\
2.04 \pm 0.19 \\
1.74 \pm 0.43\end{array}$ & $\begin{array}{l}0.72 \pm 0.12 \\
0.62 \pm 0.08 \\
0.54 \pm 0.20\end{array}$ & $\begin{array}{rr}1563 & \pm 335 \\
944 & \pm 340 \\
981 & \pm 252\end{array}$ \\
\hline VMA & $\begin{array}{l}\text { Control } \\
\text { Cast. } \\
\text { EAB }\end{array}$ & $\begin{array}{l}0.05 \pm 0.01 \\
0.06 \pm 0.01 \\
0.07 \pm 0.01\end{array}$ & $\begin{array}{l}0.19 \pm 0.01 \\
0.25 \pm 0.01 * * \\
0.21 \pm 0.03\end{array}$ & $\begin{array}{l}1.88 \pm 0.09 \\
2.11 \pm 0.21 \\
1.96 \pm 0.12\end{array}$ & $\begin{array}{l}6 \cdot 0 \pm 1 \cdot 7 \\
8 \cdot 5 \pm 3 \cdot 3 \\
9 \cdot 1 \pm 3 \cdot 3\end{array}$ \\
\hline DMA & $\begin{array}{l}\text { Control } \\
\text { Cast. } \\
\text { EAB }\end{array}$ & $\begin{array}{l}0.08 \pm 0.01 \\
0.13 \pm 0.01^{*} \\
0.12 \pm 0.02\end{array}$ & $\begin{array}{l}0.32 \pm 0.02 \\
0.44 \pm 0.02^{*} \\
0.31 \pm 0.02\end{array}$ & $\begin{array}{l}1.98 \pm 0.17 \\
2.09 \pm 0.22 \\
1.69 \pm 0.27\end{array}$ & $\begin{array}{l}3 \cdot 1 \pm 0.7 \\
1.9 \pm 0 \cdot 8 \\
2 \cdot 0 \pm 0.5\end{array}$ \\
\hline AH-POA & $\begin{array}{l}\text { Control } \\
\text { Cast. } \\
\text { EAB }\end{array}$ & $\begin{array}{l}0.45 \pm 0.18 \\
0.35 \pm 0.11 \\
0.24 \pm 0.09\end{array}$ & $\begin{array}{l}0.76 \pm 0.18 \\
0.78 \pm 0.21 \\
0.40 \pm 0.08\end{array}$ & $\begin{array}{l}1.87 \pm 0.17 \\
2.35 \pm 0.24 \\
2.17 \pm 0.14\end{array}$ & $\begin{array}{l}6 \cdot 0 \pm 1 \cdot 3 \\
4 \cdot 9 \pm 1 \cdot 5 \\
8 \cdot 0 \pm 2 \cdot 6\end{array}$ \\
\hline
\end{tabular}

${ }^{*} P<0.05 ;{ }^{* *} P<0.01$, compared with control group. 
mean content of DOPAC, a major metabolite of dopamine, was $40 \%$ greater in control lambs than in EAB-treated lambs but this difference was not significant. In the dorso-medial area, the content of both dopamine $(+62 \%)$ and DOPAC $(+38 \%)$ was significantly greater in the castrated than in the control lambs $(P<0.05)$. The DOPAC content of the ventro-medial area was also greater in castrated than in control lambs $(+32 \% ; P<0.01)$. By far the greatest concentration of GnRH occurred in the median eminence and, although not significant, the mean value was higher $(+60 \%)$ in controls than in castrated or EAB-treated lambs (Table 1).

\section{Discussion}

In agreement with an earlier study involving passive immunization against oestradiol (Land et al., 1981) these results suggest that the low concentrations of oestrogens in the circulation of prepubertal male lambs exert a suppressive effect on testicular function. In contrast to the observations of Land et al. (1981), however, testicular growth rate was not affected by anti-oestradiol serum whereas plasma androgen concentrations were significantly raised by $74 \%$ and $37 \%$ at 12 and 16 weeks of age, respectively. Although oestradiol implants can suppress plasma levels of $\mathrm{LH}$ and FSH in intact (Jenkins \& Waites, 1983) and castrated (Schanbacher \& Ford, 1977; Alexander \& Miller, 1982) sheep, neither in the present study nor that of Land et al. (1981) were plasma LH or FSH concentrations significantly affected by removal of endogenous oestrogens.

Whilst removal of negative feedback by immunization might be expected to increase the production of both oestradiol and androgens (Nieschlag \& Wickings, 1978), the titre of antibody achieved in this study by passive immunization was capable of binding at least 132 times the circulating oestradiol concentration in male sheep (Sandford et al., 1982). The oestradiol binding capacity in EAB-treated animals, was therefore unlikely to be saturated. A feature of both the present study and that of Land et al. (1981) was the relatively small number of animals in each experimental group. This factor, together with considerable individual variation encountered within treatment groups, precludes for the present the drawing of firm conclusions regarding the ability of oestrogen feedback to modulate gonadotrophin secretion in prepubertal male sheep.

Despite the failure to demonstrate significantly enhanced gonadotrophin secretion in prepubertal male sheep passively immunized against oestradiol, our observations none the less do suggest that endogenous oestrogen may suppress testicular androgen secretion by inhibiting hypothalamic GnRH. Firstly, both control and EAB-treated lambs responded similarly to exogenous GnRH, the androgen response increasing with age as described previously (Pelletier, Carrez-Camous \& Thiery, 1981). Secondly, the dopamine content of the median eminence was significantly lower in EAB-treated lambs compared to controls which was associated with a concomitant $29 \%$ reduction in the median eminence content of its metabolite DOPAC. In rats, removal of oestradiol feedback decreases the activity of tuberoinfundibular dopaminergic neurones which, it has been proposed, mediate the suppressive action of the steroid on GnRH secretion (Fuxe et al., 1982). Since differences in the dopamine and DOPAC contents of the dorsomedial hypothalamus were also apparent between castrated and EAB-treated lambs, it is possible that testicular hormones other than oestradiol are able to influence dopamine metabolism in the hypothalamus. Thirdly, although the difference was not significant, the mean content of GnRH in the median eminence of control lambs was $60 \%$ higher than in the EAB-treated or castrated lambs, an observation which is consistent with reports of a castration induced fall in hypothalamic GnRH content in the rat (Shin \& Howitt, 1976; Chen, Geneau \& Meites, 1977). This difference presumably reflects a depletion of $\mathrm{GnRH}$ reserves in median eminence nerve terminals, resulting from a high secretion rate in EAB-treated and castrated lambs.

Schanbacher (1984) has reported that active immunization of adult rams against oestradiol increased both pulsatile LH secretion and plasma testosterone concentrations, observations which also suggest that oestradiol may exert its inhibitory effect on testicular function by suppressing 
hypothalamic GnRH output. The demonstration of specific oestrogen receptor sites in the hypothalamus of the ram (Pelletier \& Carraty, 1981; Glass, Amann \& Nett, 1984) further supports this view. The present study provides additional evidence for a role of endogenous oestrogen in the regulation of the hypothalamic-pituitary-testicular axis of the developing lamb and emphasizes the need for further work in this area.

We thank Dr F. J. Cunningham, E. Henley, J. Hostford and J. Barber for assistance and G. W. Aherne for the gift of anti-methatrexate serum. This work was supported by the Agriculture and Food Research Council with grants AG 45/192 to G.M.H.W. and AG 90/9 to B.A.M.

\section{References}

Alexander, D.C. \& Miller, W.L. (1982) Regulation of ovine follicle-stimulating hormone $\beta$-chain mRNA by $17 \beta$-estradiol in vivo and in vitro. J. biol. Chem. 257, 2282-2286.

Chen, H.T., Geneau, J. \& Meites, J. (1977) Effects of castration, steroid replacement and hypophysectomy on hypothalamic LHRH and serum LHRH. Proc. Soc. exp. Biol. Med. 15, 127-131.

Fuxe, K., Andersson, K., Blake, C.A., Eneroth, P., Gustafsson, J.A. \& Agnati, L.F. (1982) Effects of estrogen and combined treatment with estrogen and progesterone on central dopamine, noradrenaline, and adrenaline nerve terminals of the ovariectomized rat. Relationship of changes in amine turnover to changes in LH and prolactin secretion and in sexual behaviour. In Steroid Hormone Regulation of the Brain, pp. 73-92. Eds K. Fuxe, J. A. Gustafsson \& L. Wetherberg. Pergamon, Oxford.

Glass, J.D., Amann, R.P. \& Nett, T.M. (1984) Effects of season and sex on the distribution of cytosolic estrogen receptors within the brain and the anterior pituitary gland of sheep. Biol. Reprod. 30, 894902 .

Howles, C.M., Webster, C.M. \& Haynes, N.B. (1980) The effect of rearing under a long or short photoperiod on testis growth, plasma testosterone and prolactin concentrations and development of sexual behaviour in rams. J. Reprod. Fert. 60, 437-447.

Jenkins, N. \& Waites, G.M.H. (1983) Effects of hemicastration at various ages and of oestradiol- $17 \beta$ on plasma concentrations of gonadotrophins and androgens, testicular growth and interstitial cell responses in prepubertal lambs. J. Reprod. Fert. 67, 325-334.

Knight, P.G., Wilson, S.C., Gladwell, R.T. \& Cunningham, F.J. (1984) Hypothalamic contents of LHRH and catecholamines during the ovulatory cycle of the hen (Gallus domesticus). J. Reprod. Fert. 71, 289- 295.

Land, R.B., Baird, D.T. \& Carr, W.R. (1981) Increased testicular growth of Tasmanian Merino ram lambs treated with antisera to oestrogens. J. Reprod. Fert. $62,151-158$.

Land, R.B., Morris, B.A., Baxter, G., Fordyce, M. \& Forster, J. (1982) Improvement of sheep fecundity by treatment with antisera to gonadal steroids. $J$. Reprod. Fert. 66, 625-634.

Lee, V.W.K., Bremner, W.J., Cumming, I.A., de Kretser, D.M. \& Findlay, J.K. (1981) Effects of LH-RH infusion, castration and cryptorchidism on gonado- trophin and testosterone secretion in developing rams. J. Reprod. Fert., Suppl. 30, 111-118.

Nieschlag, E. \& Wickings, E.J. (1978) Biological effects of antibodies to gonadal steroids. Vitamins and Hormones 36, 165-202.

Nishihara, M. \& Takahashi, M. (1983) Effects of active immunization against estradiol-17 $\beta$ on luteinizing hormone and testosterone in male rats. Biol. Reprod. 29, 1092-1097.

Pelletier, J. \& Carraty, A. (1981) Characterization of cytosolic $5 \alpha$-DHT and $17 \beta$-estradiol receptors in the ram hypothalamus. J. Steroid Biochem. 14, 603-609.

Pelletier, J., Carrez-Camous, S. \& Thiery, J.C. (1981) Basic neuroendocrine events before puberty in cattle, sheep and pigs. J. Reprod. Fert., Suppl. 30, 91-102.

Sandford, L.M., Simaraks, S., Palmer, W.M. \& Howland, B.E. (1982) Circulating estrogen levels in the ram: influence of season and mating and their relationship to testosterone levels and mating frequency. Can. J. Anim. Sci. 62, 85-93.

Schanbacher, B.D. (1984) Regulation of LH secretion in male sheep by endogenous estrogen. Endocrinology $115,944-950$.

Schanbacher, B.D. \& Ford, J.J. (1977) Gonadotropin secretion in cryptorchid and castrate rams and the acute effects of exogenous steroid treatment. Endocrinology 100, 387-393.

Shin, S.H. \& Howitt, C.J. (1976) Effect of testosterone on hypothalamic LH-RH content. Neuroendocrinology 21, $165-174$.

Walton, J.S., McNeilly, J.R., McNeilly, A.S. \& Cunningham, F.J. (1977) Changes in the concentrations of follicle-stimulating hormone, luteinizing hormone, prolactin and progesterone in the plasma of ewes during the transition from anoestrus to breeding activity. J. Endocr. 75, 127-136.

Waites, G.M.H., Speight, A.C. \& Jenkins, N. (1985) The maturation of Sertoli cells and Leydig cells in the mammalian testis. J. Reprod. Fert. 75, 317-326.

Webley, G.E. (1982) A study of aspects of the reproductive physiology in the male and female grey squirrel (Sciurus carolinensis). Ph.D. thesis, University of Reading.

Welento, J., Szteyn, S. \& Milart, Z. (1969) Observations on the stereotaxic configuration of the hypothalamus nuclei in the sheep. Anat. Anz. 124, S1-27.

Received 17 February 1986 